\title{
The dynamics of Arthropod diversity and abundance in rice field ecosystem in Central Lombok, Indonesia
}

\author{
RUTH STELLA PETRUNELLA THEI ${ }^{1, \vartheta}$, ABDUL LATIEF ABADI ${ }^{2}$, GATOT MUDJIONO ${ }^{2}$, DIDIK SUPRAYOGO ${ }^{2}$ \\ ${ }^{1}$ Faculty of Agriculture, Universitas Mataram. Jl. Majapahit 62, Mataram 83125, West Nusa Tenggara, Indonesia. \\ Tel./fax.: +62-370-621435, `email: rstellapt@gmail.com \\ ${ }^{2}$ Faculty of Agriculture, Universitas Brawijaya. Jl. Veteran, Malang 65145, East Java, Indonesia
}

Manuscript received: 9 September 2020. Revision accepted: 28 November 2020.

\begin{abstract}
Thei RSP, Abadi AL, Mudjiono G, Suprayogo D. 2020. The dynamics of Arthropod diversity and abundance in rice field ecosystem in Central Lombok, Indonesia. Biodiversitas 21: 5850-5857. Arthropods have roles as pests, decomposers, pollinators, and natural enemies of pests. Natural enemies play a vital role in pest population control by predation or parasitism. A study of the arthropod community in the rice field ecosystem was conducted in Central Lombok, Indonesia from December 2009 to March 2010 in order to elucidate the composition, structure, and dynamic diversity of arthropods present. Arthropod sampling was done by pitfall traps, yellow pan traps, and insect net. Arthropod dynamic diversity, especially of natural enemies, was determined by diversity index, dominance index, evenness analysis, and pictorial analysis. Based on taxonomical perspective, as many as 98 arthropod species were found, including 85 insect species from 59 families and 9 orders; and 13 spider species in 6 families. Based on the ecological functions, predator arthropods were the most common (33 species, dominated by spiders), but the phytophage arthropods had the most species richness (49.34\%). A high Shannon index (3.18) and Pilou index (0.7) indicated dominant arthropods in the ecosystem. Arthropod species richness and diversity increased alongside rice development and decreased after harvest.
\end{abstract}

Keywords: Arthropods, diversity, rice field ecosystem, species richness

\section{INTRODUCTION}

An agroecosystem, just like any other ecosystems, contains biotic and abiotic components that interact with each other which affect the growth and development of the biotic components (Altieri 1995). One of the biotic components of an agroecosystem is arthropods, which have roles in the ecosystem as pests, decomposers, pollinators, and natural enemies of pests. As pests would lower agricultural production, natural enemies are an important part of the ecological process as they can control pest populations through parasitism or predation.

In rice field agroecosystem, natural predators of pests are various and abundant (Bambaradeniya 2000). For example, Laba (2001) stated that no less than 700 species of insects, including parasitoids and predators, were found in rice field ecosystems without any pest infestations, such as brown leafhoppers. Settle et al. (1996) documented 765 spider species in a rice field ecosystem with irrigation in Indonesia. Bambaradeniya and Amerasinghe (2008) noted that spiders comprised more than $50 \%$ of arthropods in Sri Lankan rice fields. As many as 46 predators and 14 parasitoid species were found in rice fields in the Philippines (Heong et al. 1991). Those studies indicate that natural predators can adapt to continuously disturbed ecosystems such as in rice fields. The high adaptability of natural predators makes them feasible to be used in annual crop agroecosystems.

Nowadays, as agroecosystems become modernized, high energy inputs are often involved, including the use of chemical fertilizers, pesticides, and other agricultural chemicals. The excessive use of those chemicals are already shown to cause pervasive ecological results and imbalances in the ecosystem. Imbalances in ecosystem are caused by poorly managed environment without regard to any ecological principles (Altieri and Nicholls 2004). Altieri and Nicholls (2004) stated that ecosystem management and agricultural practice may affect the diversity of predators and pests. This suggests that the lack of ecological balance and sustainability may cause continuous pest attack, erosion, water pollution, and so on. The uses of agricultural cultivation technologies and agrochemical applications are often harmed the natural enemies of the pests, depleting the ecological services provided by the agroecosystem and eventually collapsing the environment.

Some previous studies on arthropods in rice field ecosystems in Indonesia have been reported (Karenina et al. 2019; Prabawati et al. 2019; Herlinda et al. 2020; Wakhid et al. 2020). Prabawati et al. (2019) reported that the abundance of canopy arthropods in South Sumatra (Indonesia) freshwater swamp main and ratooned rice applied with bioinsecticides and synthetic insecticide. Karenina et al. (2019) showed that herbivore population and the lowest of spiders abundance in rice field ecosystems with synthetic insecticide application and significantly different with population in rice field ecosystems with refugia. The lowest of predatory insect abundance in plots with Abamectin applications reduced the parasitoid and herbivore number in freshwater swamps 
of South Sumatra, Indonesia (Herlinda et al. 2020). Furthermore, the aquatic insect community in rice field ecosystems also reported in Bogor, West Java, Indonesia (Wakhid et al. 2020). However, there is little information about arthropods diversity and abundance of dinamics in rice field ecosystem in Central Lombok, West Nusa Tenggara Province, Indonesia. Our present study could enrich the existing knowledge on agroecosystem entomology in tropics, particularly in Lombok Island.

This study aimed to elucidate the diverse dynamic of arthropods in rice field ecosystems in Lombok Island and to reveal the community composition of pest and natural enemy arthropods in rice fields and the ecosystem surrounding them. We expected the results of this study can help the management of rice field ecosystems and the ecosystems surrounding them in hope to create greater sustainability.

\section{MATERIALS AND METHODS}

\section{Study period and area}

The study was conducted from December 2009 to March 2010. Arthropods were sampled in three acres of rice fields located in Puyung Village, Central Lombok District, West Nusa Tenggara Province, Indonesia (Figure 1). The seeding, planting, fertilization, and management of rice were based on local practices following the technical standards prescribed by company partner.

\section{Sampling methods}

Sampling was performed starting from two weeks after rice planting until one week after harvest with a 14-day sampling interval. Swing nets (20 double swings) were used to sample arthropods in the plant canopy while 60 yellow pan traps with 3 repetitions were placed at an equal distance between them throughout the sampling area.
Ground surface arthropods were sampled by pitfall traps, with the same setting as the yellow pan trap (60 traps in total with 3 times repetition). All traps were set and collected after 24 hours. Every trapped arthropod was submerged in ethyl acetate, filtered out of the liquid with filter paper, rinsed with tap water, stored in $70 \%$ alcohol solution, and transferred to the laboratory for identification. Kalshoven (1981), Lawrence and Britton (1994), and Hadlington and Johnston (1987) manuals were used for sample identification and species identifications were recorded. Sample identification was performed at Mataram University and the Zoology Lab, Research Center for Biology, Indonesian Institute of Sciences (LIPI), Cibinong.

\section{Data analysis}

Data were analyzed for: (i) diversity index (Eq. 1) (Rahayu et al. 2006); (ii) dominance index (Eq. 2); (iii) evenness index (Eq. 3) (Ludwig and Reynolds 1988); and species similarity (Eq. 4) (Southwood 1980).

$$
\begin{aligned}
& \mathrm{H}^{\prime}=-\sum \text { pi In pi } \\
& \mathrm{Pi}=\text { Proportion of species } \mathrm{i} \\
& \mathrm{D}=\frac{\mathrm{ni}}{\mathrm{N}} \times 100 \% \\
& \mathrm{Ni}=\text { Total of Species } \mathrm{I}, \mathrm{N}=\text { Total sampled } \\
& \mathrm{E}=\mathrm{H}^{\prime} / \mathrm{In}(\mathrm{S}) \\
& \mathrm{H}^{\prime}=\mathrm{Diversity} \mathrm{index,} \mathrm{S}=\text { Species count }_{\mathrm{Cs}=2 \mathrm{j} /(\mathrm{a}+\mathrm{b})}
\end{aligned}
$$$$
\mathrm{Ni}=\text { Total of Species I, } \mathrm{N}=\text { Total sampled individual }
$$

Where; $\mathrm{a}=$ Total species in habitat $\mathrm{a}, \mathrm{b}=$ Total species in habitat $b, j=$ Total of same species found in $a$ and $b$ habitat
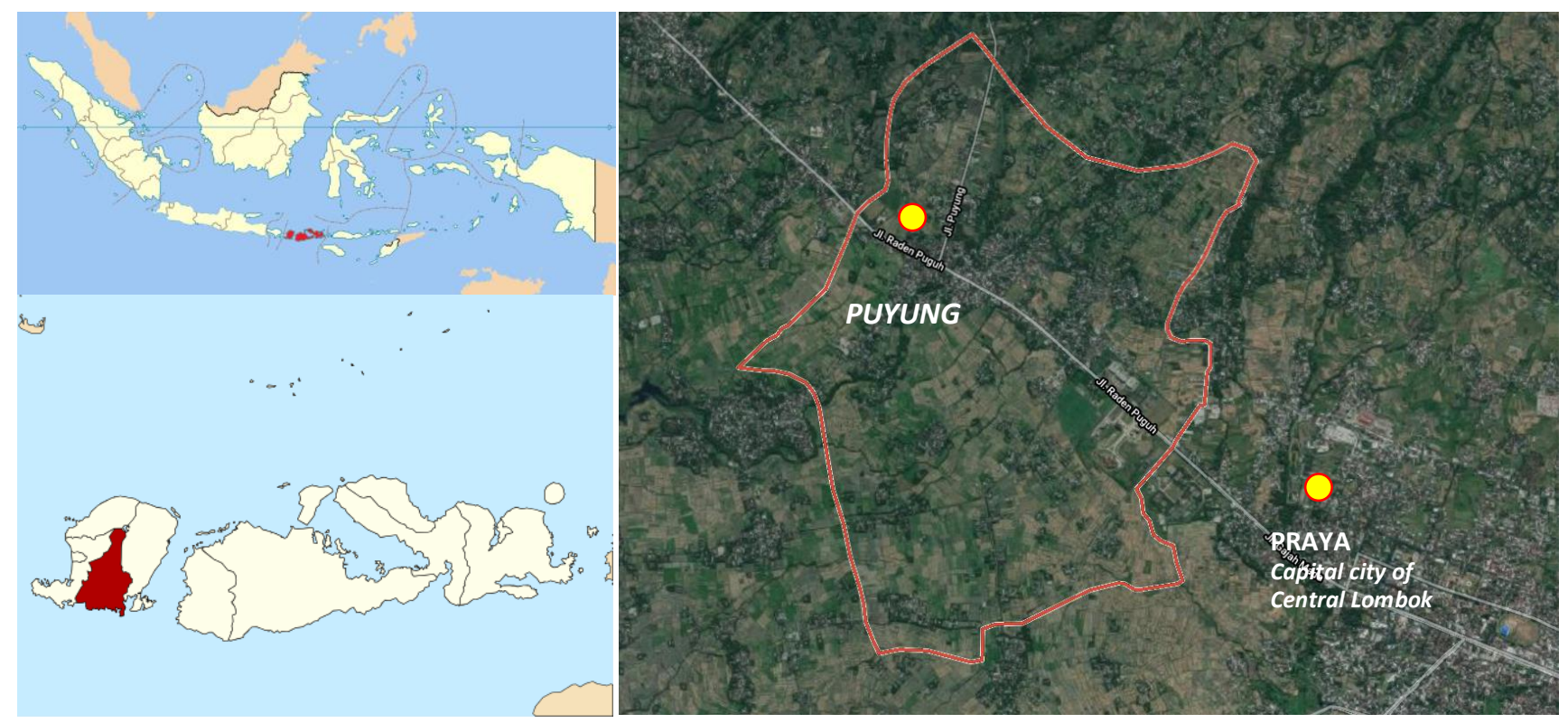

Figure 1. Map of study site in Puyung Village, Central Lombok District, West Nusa Tenggara Province, Indonesia area showing location of sampling sites (marked with black arrow) 


\section{RESULTS AND DISCUSSION}

\section{Arthropods composition and richness based on taxonomy}

The Coleoptera (17 species from 8 families) was dominated by the Carabidae family (4 species) and Coccinellidae (3 species). Aranae was the third biggest arthropod group in the sample, consisting of 13 species in 6 families with Lycosidae and Araneidae as the most sampled family. Twelve species from 7 families of Hemiptera and 11 species from 11 families of Diptera were sampled during the study. Tetrigidae dominated in Orthoptera samples, with 8 species and 7 families. Cicadellidae was the dominating family from Homoptera ( 8 species and 6 families). The sampling found 5 species and 5 families of Lepidoptera and 5 species and 3 families of Odonata. Baetidae was the only family of Ephemeroptera collected during the sampling (Figure 2).

\section{Arthropods composition and richness based on ecological function}

Based on their ecological function, all samples could be divided into 33 predator species, 7 parasitoid species, 30 phytophage species, 8 decomposers, 10 pollinators, and 10 arthropod species with other ecological functions (Figure 3 ). Based on ecological function, all obtained arthropods could be divided into 33 predator species $(1$ species of Hymenoptera, 7 species of Coleoptera, 4 species of Diptera, 3 species of Hemiptera, 5 species of Odonata, and 13 species of Araneae), 7 species of parasitoid (6 species of Hymenoptera and 1 species of Diptera), and 30 species of phytophage (6 species of Coleoptera, 1 species of Diptera, 4 species of Lepidoptera, 8 species of Hemiptera, 5 species of Orthoptera, and 6 species of Homoptera), 10 species of Hymenoptera of Pollinator, 8 species of decomposers (4 species of Coleoptera, 1 species of Diptera, and 3 species of Orthoptera), and 10 species of others (1 species of
Hymenoptera, 4 species of Diptera, 1 species of Lepidoptera, 1 species of Hemiptera, 1 species of Orthoptera, and 2 species of Homoptera). The ratio of natural enemies (predator and parasitoid) to phytophages is 1.33: 1 .

The diversity index (Shannon) of arthropods in the rice field ecosystem was fairly high (3.18) in comparison with nearby dikes (3.04), bushes (3.06), and irrigation banks (3.13) but with the relatively low $(<1)$ evenness index in sampling places $(0.70 ; 0.76 ; 0.79$; and 0.81 for rice fields, dikes, bushes, and irrigation banks, respectively) indicating that the richness between individuals is not even in every sampling site (Table 1). The higher the number of both indices indicate that the arthropod community is more diverse in that particular place. The Margalef index (R) also suggests that the rice field has the most arthropod species richness (11.09).

Observation data during the rainy season (December 2009-March 2010) showed that relative richness of phytophages in rice fields was higher $(51.38 \%)$ than all of the other functional groups (Table 2). The different methods produced different results: phytophage relative richness was $61.21 \%$ in the net swing trap and $18.87 \%$ in yellow pan trap. Arthropods that reside in vegetation were mostly captured by the net-swinging method. The leaf locust Atractamorcha creatives and Oxya sp. (both are Acrididae) were $74.16 \%$ of all captured arthropods. Pardosa spiders, Carabidae bugs, and Oecephylla smaragdina ants were the most captured predators in the pitfall traps.

Natural enemy arthropods increased with a similar pattern, but this increase was slower and had a lower relative richness that peaked at 9-10 weeks after planting (Figure 4). After that, the richness of both phytophages and natural enemies decreased until the last sampling, i.e. after the harvest.

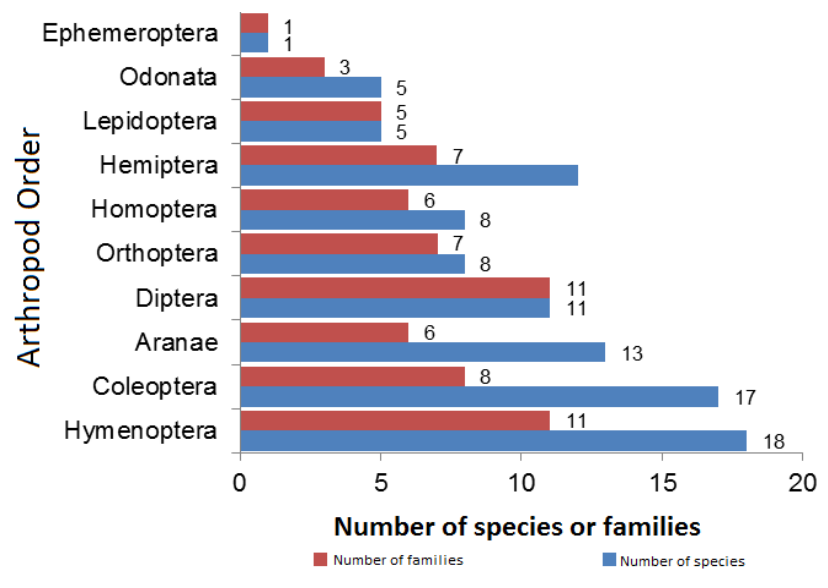

Figure 2. The composition of Arthropod species based on ecological functions in the land of rice in Central Lombok, Indonesia

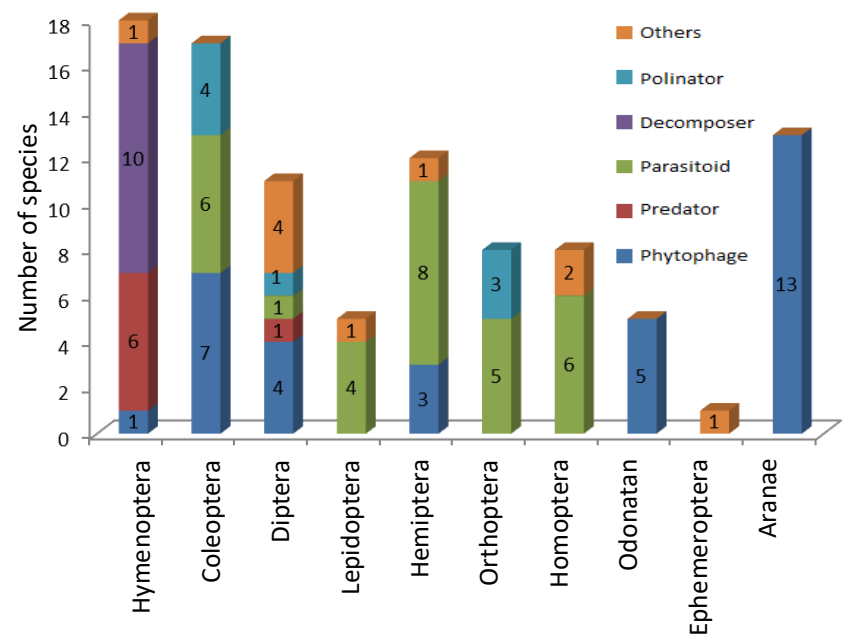

Figure 3. The composition of species and taxonomic of arthropods in rice field ecosystem in Puyung, Central Lombok, Indonesia 
Table 1. Arthropod diversity, evenness, and species richness indices in sampling area

\begin{tabular}{lccc}
\hline Habitat & $\begin{array}{c}\text { Shannon } \\
\text { Index (H') }\end{array}$ & $\begin{array}{c}\text { Pilou Index } \\
(\mathbf{E})\end{array}$ & $\begin{array}{c}\text { Margalef } \\
\text { Index (R) }\end{array}$ \\
\hline Rice field & 3.18 & 0.70 & 11.09 \\
Dike & 3.04 & 0.76 & 7.40 \\
Bushes & 3.06 & 0.79 & 7.32 \\
Irrigation bank & 3.13 & 0.81 & 7.22 \\
\hline
\end{tabular}

Table 2. Arthropod relative richness (\%) in respective traps in rice field ecosystem

\begin{tabular}{lcccc}
\hline \multirow{2}{*}{$\begin{array}{l}\text { Functional } \\
\text { groups }\end{array}$} & $\begin{array}{c}\text { Yellow pan } \\
\text { trap } \\
(\mathbf{n = 2 1 5 7 )}\end{array}$ & $\begin{array}{c}\text { Pitfall } \\
\text { trap } \\
(\mathbf{n = 7 4 2})\end{array}$ & $\begin{array}{l}\text { Net swing } \\
(\mathbf{n}=\mathbf{8 1 3 1})\end{array}$ & $\begin{array}{c}\text { Total } \\
(\mathbf{n}=\mathbf{1 1 . 0 3 0})\end{array}$ \\
\hline Phytophage & 18.87 & 38.14 & 61.21 & 51.38 \\
Predator & 31.76 & 48.92 & 30.97 & 32.33 \\
Parasitoid & 5.52 & 1.08 & 2.12 & 2.71 \\
Others & 43.86 & 11.86 & 5.71 & 13.58 \\
Total & 100 & 100 & 100 & 100 \\
\hline
\end{tabular}

\section{Predator and parasitoid composition and richness}

A total of 4039 predator individuals were observed during the study. Most of them were spiders (70.68\%) and insects (29.22\%). A total of 13 species from 6 families of spiders were collected and Tetragnathidae, horizontal web spiders, were the most abundant $(22.7 \%$ from total richness), followed by Araneidae (vertical web spiders), comprised about $21.9 \%$ of total richness; Oxyopidae, the diurnal hunter in plant spiders, comprised about $13.42 \%$; and $10.92 \%$ were Lycosidae (diurnal ground and plant hunter spiders). Salticidae (diurnal hunter in vegetation spiders) and Metidae (round horizontal web spiders) were the least observed in this study, comprised only $1.61 \%$ and $0.05 \%$ of total richness, respectively.

At least 8 species from 5 predator spider families present in rice field ecosystems: Lycosidae (1 species), Oxyopidae (2 species), Salticidae (1 species), Lynipiidae (1 species), Araneidae (2 species), and Tetragnathidae (1 species). The high relative richness may be caused by the high rainfall during the duration of the study, which suitable for spider's growth and development. The monthly rainfall totals from December 2009 to April 2010 were 53, $317,125,249$, and $152 \mathrm{~mm}$, respectively.

The relative richness of insects was $29.31 \%$ from total predators. There were 20 species from 5 orders and 12 families observed in this study. Verania lineata was the most sampled from Cocccinelidae family and Acupalpus smaragdulus Febricius var. 5-pustulatus Wiedemann (Carabidae) was the most trapped by the pitfall trap.

Parasitoids were not observed in great numbers and their ecological function was not as impactful as the predators, based on their richness and diversity. A total of 172 individuals from several species were found; 5 species from Hymenoptera; 2 species from Evaniidae; 1 species from Scelionidae; 1 species from Ichneumonidae; and 1 species from Braconidae. The other parasitoid belonged to Sarcopagidae. Individuals of Evaniidae were the most abundant, $61.63 \%$ of total individuals sampled: Prosevaria fuscipes (67 individuals), Megarhysa (Ichneumonidae) (25 individuals), Hadronatus sp. (Scelionidae) (24), Sarcopagidae (10) and Meteorus nigricolis (Braconidae) (4). The Hadronatus sp. seen is a parasitoid of Leptocorissa acutta. More than 50\% of arthoropod species at first week after plantation were natural enemies of pests (Figure 4). About 29 belonged to predator species, 2 belonged to parasitoid species, 12 belonged to phytophage species (28.57\% of all observed arthropods), and other arthropods were found. Lycosidae spiders were the most commonly found (29.82\%), mainly Hipassa sp. and Pardosa sp. At the edge of the rice field, Oechephylla smaragdina ants and Acupalpus pustulatus were the most commonly found. Salticidae spiders were easily found on the bank of the irrigation channel.

\section{Natural enemy and prey ratio}

The ecological condition of an area can be inferred by analyzing the dynamic of sampled species ecological functions during the time of sampling. This study observed much more phytophages than their natural enemy in the half end of the study, but not in the first weeks of the study. The ratio of natural enemies and their phytophage prey from the first week until the third week of the plantation were 1:0.29; $1: 0.65$, and 1:1.01, respectively (Figure 5).

Application of (2-Butan-2-ylphenyl) N-methylcarbamate (BPMC) insecticide one and two weeks after the rice planting resulted in lowering the relative richness of the arthropod community. Interestingly, phytophage relative richness increased much faster than did natural enemy richness after application. Herbicide application at 35 days after planting lowered the predator's relative richness but did not have any effect on phytophage richness. Phytophage relative richness increased gradually and reached its peak at 100-112 days after plantation. Carbamate insecticide application at 3 weeks after plantation lowered both natural enemy and phytophage relative richness, but phytophage relative richness was still higher than that of the natural enemies.

The natural enemy population slowly increased, with a similar pattern to the phytophages, and reached its peak at 9-10 weeks after planting. After that, both populations decreased until the harvesting time. Natural enemy relative richness significantly decreased during 15-21 days after planting and then increased following the trend of phytophage relative richness. The relative richness of both phytophages and natural enemies decreased during the harvesting time until the last sampling time at one week after harvest. In general, natural enemies were found from the first sampling time when the rice was planted. Total arthropods species during the first phase of rice growth (1 week after planting) were 25 species, increasing to 52 species at 7 weeks after planting, decreasing to 32 species at 14 weeks after planting, and 20 species at the harvesting time. 


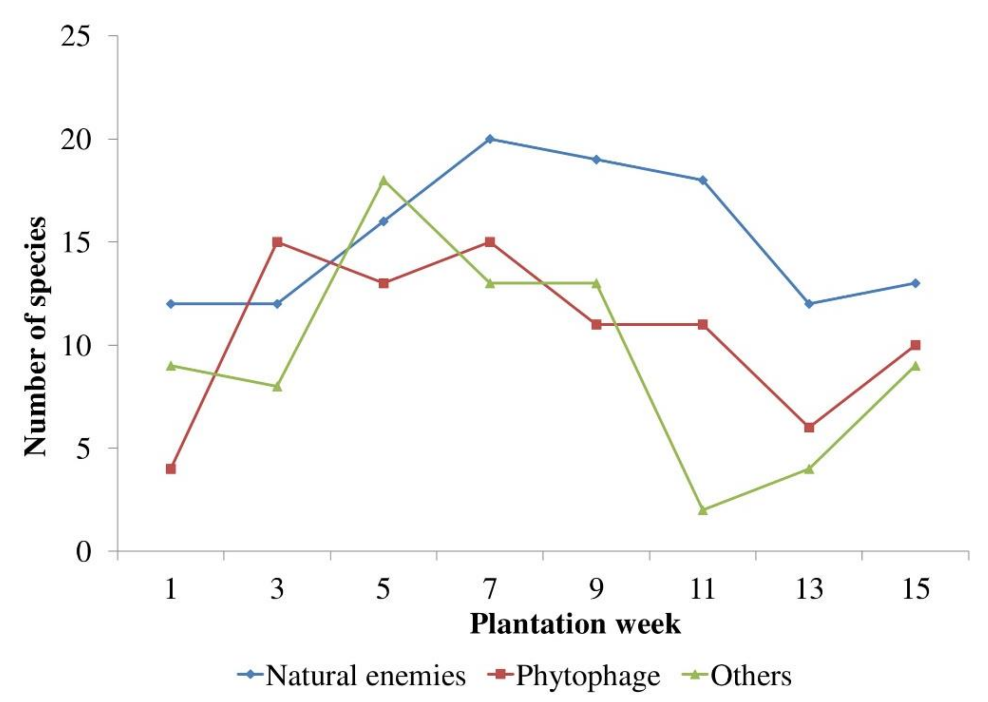

Figure 4. The dynamics of arthropod species richness in rice field in Central Lombok, Indonesia during cultivation period from December 2009 to March 2010

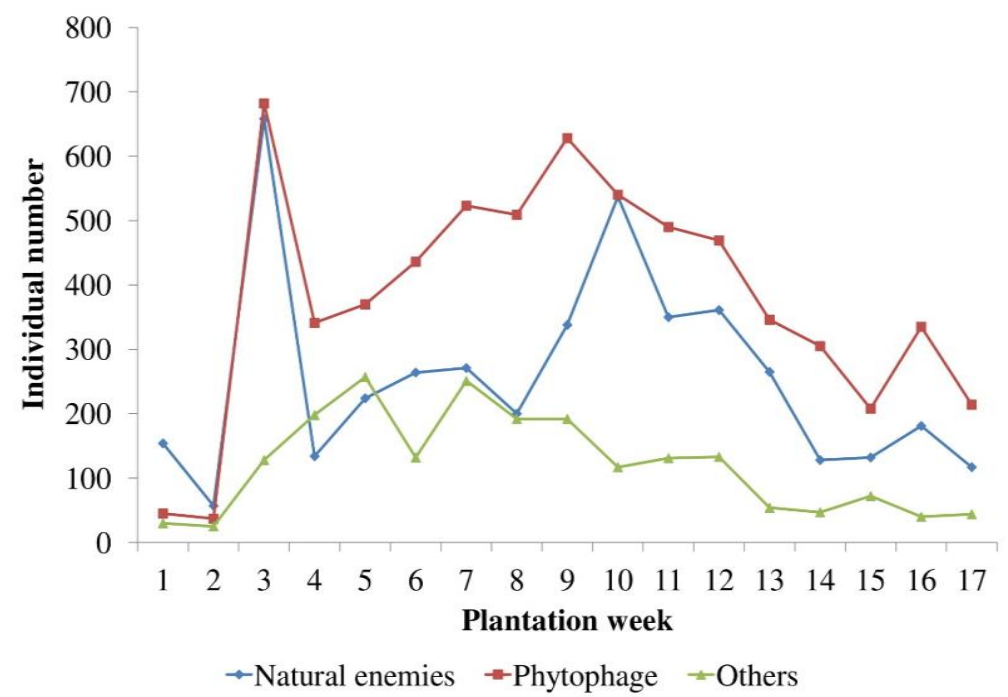

Figure 5. The population dynamics of phytophage, natural enemies, and other insects caught in rice fields in Central Lombok, Indonesia during cultivation period from December 2009 to March 2010.

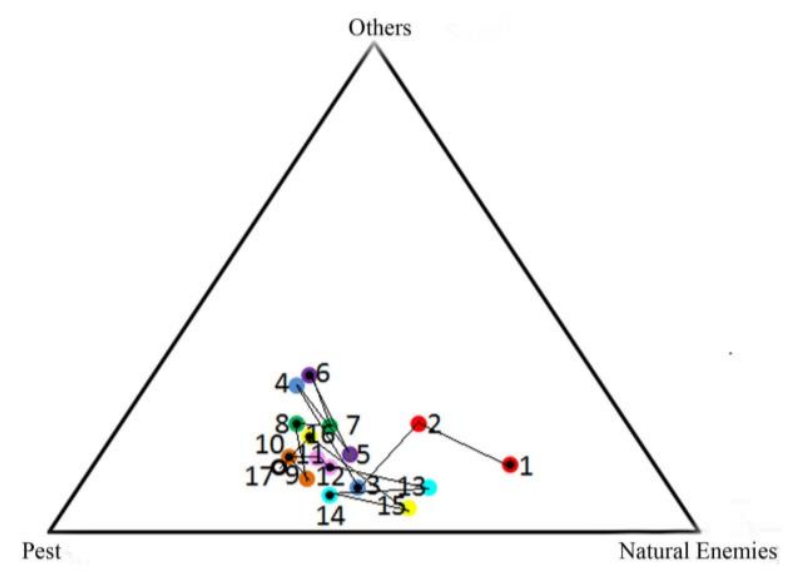

Figure 6. Ecological conditions of paddy fields by meal composition analysis pictorial role. The numbers inside the triangle indicate the observation times (there were 17 observations in this study)

\section{Environment endurance to pest organisms}

In order to investigate the dynamics of the role composition of collected individual arthropod collected, across time or location within the same landscape, the pictorial analysis was done. This method is very suitable for understanding the ecological conditions associated with the development of preventive measures in pest management. The method used is in the form of a fictional approach by using a three-dimensional graphic to describe the position of the role composition. The analysis showed that, generalist predators such as Pardosa sp., Oxyopes sp., and Oecephylla ants were commonly found in the edge, irrigation bank, and bushes. Wild vegetation on the edge of the rice fields is considered as a reservoir for predators such as spiders and Coccinellidae (Figure 6). Some of the wild vegetation on the edge were Panicum sp., Polygonum sp., Amaranthaceae, Nasturtium, Physalis angulata, and Echinochloa. 


\section{Discussion}

The total species number of sampled arthropods in the sampled rice fields during the planting period of 2009/2010 was 98, much higher than what Arifin et al. (1997) observed in the same ecosystem in Central Java (56 species). Sampled arthropods belonged to 9 insect orders and 1 spider order. Sampling data indicated that Hymenoptera species were the most abundant and represented in almost every ecological function, including predator and parasitoids for rice pests and pollinators.

The species richness of natural enemies clearly outnumbered other functions (33 predators and 7 parasitoids) and comprised almost $40 \%$ of all sampled arthropods. Arthropod species richness and high diversity index $(\mathrm{H}=3.18)$ suggest the balance of phytophages and their natural enemies, thus revealing the potential for natural pest control mechanism in the rice field ecosystems of Central Lombok. This finding is in accordance with Herlinda (2000). Relative species richness of arthropod community followed the growth of the rice in the ecosystem.

Hymenoptera parasitoids were mostly captured by yellow pan trap and predator class relative richness was fairly high in the rice field ecosystem (Table 2). This may due to the abundance of their prey and their high adaptability to the constantly changing environment. Similar results were documented by Settle et al. (1996) and Herlinda (2000). Besides that, predators have a high mobility range and a wide selection of prey. Among the predators, spiders were $70.68 \%$ of the total predators and some of them were web spiders (Tetragnathidae and Araneidae) and the others were hunter spiders (Oxyiopidae and Lycosidae). Most of their reported prey are rice pests such as leaf and stem leafhoppers and other kinds of pest (Brown et al. 2003). Spiders were observed in all rice field plantation periods, from the seedling stage even until after harvest. The highest species richness was observed during the grain ripening period of rice, as most of the prey species of the spiders were present in this period. Coleoptera and Diptera were the second and third most observed orders in terms of relative richness of predators, while Hymenoptera and Hemiptera were less observed (1.73\% and $0.62 \%$, respectively). Rhinocoris fuscipes (Reduviidae, Hemiptera) are polyphage and potential predators for tobacco pests such as Spodoptera litura (Fab.) and Noctuidae (Sujatha et al. 2012).

Pollinator arthropods were the third-largest category in terms of relative richness and all of them were members of Hymenoptera: Vespidae, Halictidae, Anthophoridae, Cabronidae, Megachilidae, and Sphecidae, with the most observed being Anthophoridae and Halictidae. Parasitoids and decomposers were the least observed in this study. Evaniidae were the most dominant parasitoid and some observed decomposers were Calliphoridae, Blatelidae, Blattidae, and Mantidae from Orthoptera. Baetis haemalia Leonard mayflies in Baetidae (Ephemeroptera) were observed and this family is widely observed as a bioindicator for water quality, environmental stress, and for evaluating the potential effect of climate change. These Ephemeroptera live in clean and calm water surfaces and have micrositae with a wax layer on the tip of their legs that are very sensitive to water pollution. If Ephemeroptera is not found in the irrigation water body, it indicates that the water is polluted and has low water quality.

The composition of arthropod community is based on the plant phenology as the physical parts of the plant available for food and habitat impact insect growth. Total species count of predators was always higher than pests in the vegetative, reproductive, and ripening states of the rice crop.

These study results suggest that many predators colonize the rice field ecosystem during the first phase of rice growth. Most of the spiders and predator insects seen were generalist predators during this phase. Lycosa spiders were usually present during the early vegetative state at the base of the rice plant and able to consume 5-15 individuals per day. Oxiopes sp. can consume up to three months per day. Scenolidae and Braconidae had been found during the early phase, even though their relative population was small. Bambaradeniya and Edirisinghe (2008) also recorded the early presence of predators in the rice field ecosystem and the total species of phytophages increased faster than predators.

A total of 4 species were sampled from Lycosidae family (30.77\% of total species), 3 species from Araneidae, 2 species from Tetragnathidae and Salticidae, and only 1 species sampled from the Matidae family. These four spiders are important generalist predators in rice field ecosystem with grasshoppers, flies, and moths as their main prey. Herlinda (2000) had similar results, in that relative richness of Tetragnathidae was the highest.

Lycosidae and Salticidae were observed from the first week after rice planting. Until 6 weeks after rice planting, likely because the physical habitat is suitable to lay webs after 6 weeks from plantation. The first step to produce webs for most spiders is to select the place to lay the web and their webbing pattern is in part based on the physical aspect of the habitat. Prey availability and the supporting physical aspect of the habitat may contribute to the observed high relative richness of Tetragnathidae. Tetragnathidae were mainly found inside the rice plantation area rather than at the edges of the rice field. Araneidae were found from the first week after planting and their number increased, as the physical habitat was able to increase its support.

The diversity of arthropods was relatively dynamic as the changes, both in taxonomical aspect and ecological function, happened in a short time frame. More arthropods were found along with the further development state of the rice plants, as the habitat was more supportive for the growth and development of arthropods. The presence of arthropods was also in accordance with other environmental factors. Arthropod richness peaked at the seventh week after planting, when the rice plant started to produce grains and then decreased at the harvesting time. The results showed that Carabidae bugs, such as Pherosopus occipitaslis, and dragonflies, such as Orthotrum sabina, Crocothemis servilia, and Copera sp. were mainly found at the grain ripening timeframe, which 
may have been caused by the abundance of the prey during this time.

This study suggested that natural enemies could invade the ecosystem much faster when the pest population was still low. It may be caused by their wide range of prey, as the most commonly found natural enemy were generalist predators or parasitoids.

Pictorial analysis revealed that the Puyung rice field sampled during the planting period of 2009/2010 was not healthy. The natural enemy presence was dependent on the pest population as prey. In extreme conditions, the natural enemy will go extinct if pest migration occurred. High relative richness at the edge of the rice field suggested that the wild vegetation was suitable habitat for the natural enemy. Karindah et al. (2011) stated that wild vegetation such as Monochoria vaginalis, Fimbristylis miliacea, Cyperus iria, and Limnocharis flava is able to sustain predator insects, especially Metioche vittaticollis and Anaxipha longipennis. The high similarity $(67 \%)$ of the arthropod community in the rice field and at its edge suggests species flow between rice field and the wild vegetation. Herlinda (2000) stated that the similarity of the two ecosystems suggests their interaction in terms of species flow. In some cases, a pictorial approach with a $3 \mathrm{D}$ graph can map the position and role composition (Triwidodo 2003).

In conclusion, the diversity of arthropods in rice field ecosystem in Puyung, Central Lombok showed quite high, namely 98 species in 65 families and 10 orders, with a Shannon diversity index value of 3.18 . The functional composition of species richness consisted of 33 predator species, 30 phytophage species, 10 pollinator species, 10 other arthropod species, 8 decomposer species, and 7 parasitoid species. The ratio of natural enemies with high phytophage groups at the beginning of the growth of rice plants, natural enemies found early in plant growth were generalist predators that do not depend on their main prey and could take advantage of alternative prey at that time. The fictional analysis showed that during the growth of rice plants, the arthropod inhabitants of rice fields in Puyung, Central Lombok were more abundant than the group of pests and natural enemies, and low of other insects. The existence of many natural enemies was supported by pest populations as a source of food.

\section{ACKNOWLEDGEMENTS}

The authors would like to thank to LPPM of Mataram University, Indonesia that has facilitated this research and publication. All author declares that there is no conflict of interest in this research.

\section{REFERENCES}

Altieri MA, Letourneau DK. 1982. Vegetation management and biological control in agroecosystems. Crop Protection 1 (4): 405-430. DOI 10.1016/0261-2194 (82)90023-0.

Altieri MA, Nicholls CI. 2004. Biodiversity and Pest Management in Agroecosystems. CRC Press, New York.
Altieri MA. 1995. Agroecology: The Science of Sustainable Agriculture. Westview Press, New York.

Arifin M, Suryawan IBG, Priyanto BH, Alwi A. 1997. Diversitas arthropoda pada berbagai teknik penanaman padi di Pemalang, Jawa Tengah. Penelitian Pertanian Tanaman Pangan 15 (2): 5-12. [Indonesian]

Bambaradeniya CNB, Edirisinghe JP. 2008. Composition, structure and dynamics of arthropod communities in a rice agro-ecosystem. Ceylon J Sci 37 (1): 23-48. DOI: 10.4038/cjsbs.v37i1.494

Bambaradeniya CNB. 2000. Ecology and Biodiversity in An Irrigated Rice Field Ecosystem in Sri Lanka. [Dissertation]. University of Peradeniya, Sri Lanka.

Brown MW, Schmitt JJ, Abraham BJ. 2003. Seasonal and diurnal dynamics of spider (Araneae) in West Virginia orchards and the effect of orchard management on spider communities. Environ Entomol 32 (4): 830-839. DOI: 10.1603/0046-225X-32.4.830

Clausen CP. 1940. Entomophagous Insects. McGraw-Hill, New York.

Disney RHL, Erzinclioglu YZ, Henshaw CD, De Howse J, Unwin DM, Withers P, Woods A. 1982. Collecting methods and the adequacy of attempted fauna surveys, with reference to the Diptera. Field Stud 5: 607-621.

Flint ML, Van den Bosch R. 1981. Introduction to Integrated Pest Management. Plenum Press, New York.

Hadlington PW, Johnston JA. 1987. An Introduction to Australian Insects. South China Printing Co, Hongkong.

Heong KL, Aquino GB, Barrion AT. 1991. Arthropod community structures of rice ecosystems in the Philippines. Bull Entomol Res 81 (4): 407-416. DOI: 10.1017/S0007485300031977.

Herlinda S, Alesia M, Susilawati, Irsan C, Hasbi, Suparman, Anggraini E, Arsi. 2020. Impact of mycoinsecticides and abamectin applications on species diversity and abundance of aquatic insects in rice fields of freshwater swamps of South Sumatra, Indonesia. Biodiversitas 21 (7): 3076-3083.

Herlinda S. 2000. Analisis Komunitas Arthropoda Predator Penghuni Lansekap Persawahan di Daerah Cianjur, Jawa Barat. [Dissertation]. Institut Pertanian Bogor, Indonesia. [Indonesian]

Kalshoven LGE. 1981. Pest of Crops in Indonesia. PT. Ichtiar Baru, Jakarta.

Karenina T, Herlinda S, Irsan C, Pujiastuti Y. Abundance and species diversity of predatory arthropods inhabiting rice of refuge habitats and synthetic insecticide application in freshwater swamps in South Sumatra, Indonesia. Biodiversitas 20 (8): 2375-2387.

Karindah S, Yanuwiadi B, Sulistiawati L, Green PT. 2011. Abundance of Metioche vittaticollis (Orthoptera: Gryllidae) and natural enemies in a rice agroecosystem as influenced by weed species. Agrivita 33 (2): $133-141$.

Laba IW. 2001. Keanekaragaman hayati arthropoda dan peran musuh alami hama padi utama dalam ekosistem lahan basah. Makalah Falsafah Sains (PPs IPB 702): 1-17. [Indonesian]

Lawrence JF, Britton EB. 1994. Australian Beetles. Melbourne University Press, Victoria.

Ludwig JA, Reynolds JF. 1988. Statistical Ecology: A Primer on Methods and Computing. John Wiley \& Sons, New York.

Odum EP. 1993. Fundamentals of Ecology. Saunders College Publishing, Philadelphia.

Prabawati G, Herlinda S, Pujiastuti Y. The abundance of canopy arthropods in South Sumatra (Indonesia) freshwater swamp main and ratooned rice applied with bioinsecticides and synthetic insecticide. Biodiversitas 20 (10): 2921-2930.

Rahayu S, Setiawan A, Husaeni EA, Suyanto. 2006. Biological control Xylosandrus compactus in multistrata coffee agroforestry: A case study from Sumberjaya Subdistrict, West Lampung. Agrivita 28 (3): 268-297.

Rauf A. 1996. Utilization of Predators and Parasitoids in Integrated Pest Management. Meeting of Utilization of Biological Agent and Pesticide of Vegetable as Controlling Facilities. OPT, Pasuruan.

Settle WH, Ariawan H, Astuti ET, Cahyana W, Hakim AL, Hindayana D, Lestari AS. 1996. Managing tropical rice pest through conservation of generalist natural enemies and alternative prey. Ecology 77 (7): 19751988. DOI: $10.2307 / 2265694$.

Southwood TRE. 1980. Ecological Methods; With Particular Reference to the Study of Insect Populations. Chapman and Hall, London.

Sujatha S, Vidya LS, Sumi G. 2012. Prey-predator interaction and infochemical behavior of Rhynocoris fuscipes (Fab.) on three agricultural pests (Heteroptera: Reduviidae). J Entomology 9 (2): 130-136. DOI: 10.3923/je.2012.130.136. 
Swift MJ, Anderson JM. 1993. Biodiversity and ecosystem function in agricultural systems. In: Schultze ED, Mooney H (eds.). Biodiversity and Ecosystem Function. Springer-Verlag, Berlin.

Triwidodo H. 2003. Planning \& Analyzing Planning for Biodiversity Research \& Community Ecology. Institut Pertanian Bogor, Bogor. [Indonesian] van Emden HF, Dabrowski ZT. 1997. Issues of biodiversity in pest management. Insect Sci Appl 15: 605-620.

Wakhid, Rauf A, Krisanti M, Sumertajaya IM, Maryana N. Species richness and diversity of aquatic insects inhabiting rice fields in Bogor, West Java, Indonesia. Biodiversitas 21 (1): 34-42. 